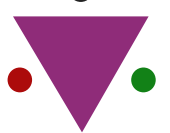

IJCRR

Section: Healthcare Sci. Journal Impact Factor: 6.1 (2018) ICV: 90.90 (2018)

(c) (1) (8)

Copyright@IJCRR

\title{
Basti Chikitsa for Healthy Life in Present Scenario: A Review
}

\section{Shilpa M. Gabhaneㄹ, Geeta V. Sathavane², Dheeraj Zade ${ }^{3}$, Arun Wankhede ${ }^{4}$, Swarupa Chakole ${ }^{5}$}

\begin{abstract}
'Professor, Rognidan-Vikritivigyan, Datta Meghe Ayurvedic Medical College, Hospital and Research Centre, Wanadongari, Nagpur, MS, India; 'Associate Professor, Rognidan-Vikritivigyan, Datta Meghe Ayurvedic Medical College, Hospital and Research Centre, Wanadongari, Nagpur, MS, India; ${ }^{3}$ Associate Professor, Dravyaguna, Datta MegheAyurvedic Medical College, Hospital and Research Centre,

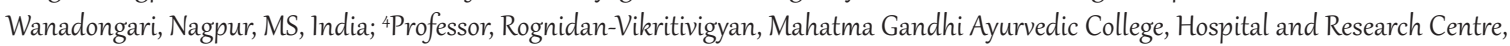
Salod, Wardha, , MS, India; 5 Professor Department Community Medicine Jawaharlal Nehru Medical College, Datta Meghe Institute of Medical Sciences, Sawangi (Meghe), Wardha, MS, India.
\end{abstract}

\section{ABSTRACT}

Introduction: In the present scenario, it is very difficult to maintain our health and lifestyle balance. Ayurveda is an ancient medical science and has a solution for this situation in the form of Panchakarma. As stress and busy life schedule cause the vitiation of Vata, among Panchakarmas -especially Basti is very effective in maintaining our healthy life because Basti maintains the proper functions of Vata. When Vata has maintained properly then the normal physiological body function runs properly and decrease the chances of disease. As Vata regulates all functions of our body, we should maintain the equilibrium of Vata in our body to keep it healthy. Basti is also very useful to maintain the disorder of Vata such as hemiplegia, muscular dystrophy, sciatica, Parkinsonism, cerebral palsy. Along with digestion and metabolism, Basti maintains our inner beauty as well as our outer beauty.

Conclusion: Basti is very useful in infertility. It is also useful in mental disorders. That's why Acharyas say," Basti is half treatment for any diseases". Basti is not only useful for a diseased person but also in healthy persons. In diseased person it cures disease and in normal person it maintains health.

Key Words: Ayurveda, Panchkarma, Vata, Basti, Healthy life

\section{INTRODUCTION}

In a present era, the human being is prone for numerous degenerative issues, because of modern lifestyle, professional stress, food habits etc. ${ }^{1,2}$ Lifestyle related disorders like hypertension and diabetes, reported especially in young adults are a prior concern. ${ }^{3-7}$ Association between different diseases like cardiac dysfunction and chronic liver diseases have also been reported. ${ }^{6,8}$ In such disorders Ayurveda management is very useful and satisfactory because of its long-lasting effects and multisystemic regenerative actions without any harm. ${ }^{6}$ Panchakarma is a comprehensive system of knowledge and practice to purify the body from the degenerative influence of toxins and restore it to balance with natural laws.

In Ayurveda, there are two types of Karmas Shaman Karma and Shodhana Karma. In Shodhana Karma there are five types of Karma such as Vaman, Virechana, Basti, Nasya and Raktamoshana. Among the Shodhana Karma, Bastikarma is considered as prime as it can provide relief in Koshtagata, Dhatugata, Marmagata andSarvashareergatavikara ${ }^{9}$ Basti is one of the major treatment modality that comes under Yuktivyapashraya Chikitsa. As Vata is responsible for disjunction and conjunction of faeces, urine, bile etc. with their receptacles, there is no remedy other than Basti for the pacification of Vata when it is aggravated severely. Hence Basti is said as half medicine or even whole medicine by Acharyas. The rectal absorption can prove the good alternative route of drug administration as it provides partial avoidance of first portal pass metabolism. It has been demonstrated that the rectal route is more efficient than even the intravenous route. ${ }^{6,10}$

Ayurveda aims mainly at maintaining the health of healthy persons and recovering the deceased persons. ${ }^{6}$ As per this

\section{Corresponding Author:}

Dr. Shilpa M. Gabhane, Professor, Rognidan-Vikritivigyan, Datta Meghe Ayurvedic Medical College, Hospital and Research Centre, Wanadongari, Nagpur, India; Mob: 9422833120; Email: mungle.shilpa@gmail.com

ISSN: 2231-2196 (Print)

Received: 22.06 .2020
ISSN: $0975-5241$ (Online)

Revised: 24.07 .2020
Accepted: 26.08 .2020
Published: 22.09 .2020 
view, Basti is used not only for the diseased person but it used in a healthy person. It seems to be very effective concerning immunity. Basti provides equilibrium of Dosha, Dhatu, Malas, provided person should follow Dinacharya and Ritucharya. Shodhana in the form of Basti possesses benefits like disease preventive, curative and health promotive. Thus, this is the relevance of Basti in healthy person for its immunity. Keeping this in view, this article has highlighted the relevance of Basti Karma in diseased person as well as healthy persons to cures the disease and maintains health respectively.

\section{AIMS AND OBJECTIVE}

- To discuss, evaluate and elaboration of Bastichikitsa in a healthy person.

- To discuss, evaluate and elaboration of Bastichikitsa in diseased persons.

Material and Methods: Ayurvedic classical text such as Charak Samhita, Sushrut Samhita, Ashtanghrudaya etc. and other literature were reviewed critically and scientifically to compile the concept of Basti. Modern scientific literature describing the mechanism of absorption was reviewed critically. Further, data available data on web-based sources and article published on the internet were compiled.

\section{Literary review of Basti}

Basti karma means enema which is medicated. In this process, medicated decoctions and oils are administered via anus in the body with the aid of instruments specially designed for the process of Basti. Basti karma's place of action is Pakwashaya which is Vata Dosha's main site. ${ }^{11}$ Hence it is the major treatment modality for Vata Dosha. It is the major treatment modality for Vata Dosha. Vāta is considered as the cause of all type of movements of the body and is the main etiological factor in the pathogenesis of various diseases. ${ }^{12}$ Apan Vayu is responsible for the elimination and retention of faeces, urine and other excreta. ${ }^{13}$ Vata is mainly located in the large intestine.

Basti sustains the age, improves strength, digestive fire, intellect, voice, and complexion and provides a happy life. The body performs all its functions smoothly. ${ }^{14}$ It is very beneficial for all age groups. The bioavailability of the drug i.e. the part of the drug increases when given as Basti. According to Acharya Sushrut, Basti works as plant watered at its root and then root circulate it in all branches. ${ }^{15}$ It has also been described as $\mathrm{Ar}$ dha Chikitsa i.e. half treatment for the management of diseases. ${ }^{16}$ The age of administration of Basti starts from one year.

\section{Classification of Basti}

According to the consistency of the drugs, Basti is broadly divided into two types
Niruha Basti (Aasthaapana) and Anuvasan Basti

Niruha Basti/ Aasthaapana Basti,- Decoction of medicinal plants is the major content of this Basti, other ingredients like honey, Saindhava, Sneha, Kalka, Prakshepa Dravya are also included to form a suspension. Niruha means to eliminate. This Basti eliminates morbid Doshas from the body. It is also known as Asthapan which means to establish life span and sustains age. ${ }^{17} 12$ Prasuta i.e. approximately $1200 \mathrm{ml}$ is the quantity of Niruha Basti for administration. The quantity of Sneha to be added depends upon the dominance of Dosha. 18

Vata dominance- 6 Pala i.e. $1 / 4^{\text {th }}$ of Niruha Bastidravya

Pitta dominance- 4 Pala i.e. 1/6 $6^{\text {th }}$ of Niruha Bastidravya

Kapha dominance- 3 Pala i.e. $1 / 8^{\text {th }}$ of Niruha Bastidravya

Sneha Basti/Anuvasan - In this type medicated Sneha in the form of Oil/ Ghee, lipids are administered. Anuvasan means to stay, the administrated medicines stay inside for a longer period, without causing any harm. It can be given daily.

Sneha Basti again subdivided according to the quantity of Sneha(oil) into two types. ${ }^{19}$

Anuvasana Basti- $1 / 4^{\text {th }}$ of the quantity of Niruhabasti

Matra Basti- $1 / 2^{\text {th }}$ of the quantity of Anuvasanabasti

The number of Basti to be given according to the need of the patient, Basti is divided into ${ }^{20}$

Karma -30 Basti

Kala -16 Basti

Yog -8 Basti

Anuvasana and Niruha Basti are given alternately. Rasayana and Burhan Basti can be given to the geriatric person. Dosha shaman Basti is preferred for the young person as metabolic activities are at its peak level. Varnya Basti is preferred for the people who are more beauty conscious. Lekhan Basti can be given to the obese person or who want to be loose their extra fats. Vrushya Basti can be given in infertility. Burhan Basti can be given to the children for their normal growth and development. The person who is habituated with heavy work or heavy exercise can undergo Matra Basti. Matra Basti has an advantage as the person does not need to follow any special Pathya.

Bastikala (Time factor for Basti)-According to various authors, Basti in a healthy person can be given in Varsharitu. Varsharutu is the best time for Basti because in this season Vataprakopa is present in the body as well as in the environment. ${ }^{21}$ Usually, NiruhaBasti is given in the morning because evening time is the period of Vataprakopaka and Niruha Basti causes Vataprakopa. This is the reason why snehadravya is added to NiruhaBasti. AnuvasanaBasti can be given in the evening. Basti can also be given according to age, Rutu, Kala, etc. 
Indications ${ }^{22}$ - Vatajvikara(hemiplegia, muscular dystrophy, sciatica, parkinsonism, cerebral palsy), diseases related to muscles and bone, Rheumatic diseases, Vibandha(constipation), abdominal distension, delayed mild stone in children, Ashmari(kidney stone, bladder stone), Jeerna Jwara(chronic fever), Niramaatisar(chronic diarrhoea).
Contraindication- Krusha(very emaciated), Amatisara(Acute diarrhea), Chhardi (vomiting), Kasa (cough), Shwas (asthma), Madhumeha (Diabetes), Shoonapayu (inflamed anus), Kritahara (immediately after taking food) Table 1 .

Table 1: Shows Basti according to diseases ${ }^{23-26}$

\begin{tabular}{|c|c|c|c|}
\hline $\begin{array}{l}\text { Sr. } \\
\text { No. }\end{array}$ & Basti Prakar & Ingredients & Diseases \\
\hline 1 & Vaitrana Basti & $\begin{array}{l}\text { Amlika (Emali), Guda, Saindhava, Gomutra and Tilataila in the } \\
\text { proportion of 4:2:1:16 }\end{array}$ & Amavata \\
\hline 2 & Kal Basti & Dashmula, Triphala & Amavata \\
\hline 3 & $\begin{array}{l}\text { PicchaBastiMocharasa } \\
\text { Basti }\end{array}$ & $\begin{array}{l}\text { Mocharasa -5o gm 2. Dugdha (Milk) -2 litres 3. Ghrita -8o ml } 4 . \\
\text { TilTaila -20 ml 5. Mulethi Kalka -40 gm }\end{array}$ & Atisaar, Pravahika \\
\hline 4 & Lekhana Basti & $\begin{array}{l}\text { Triphala Tail - 16oml, Putayavanadikalka - 96gms, Tiphalad } \\
\text { iQauth- 48oml, Shuddha Shilaajti, Kasis, Hingu, Tuttha-, Yavk- } \\
\text { shaar, Saindhava 12gm each, Madhu- 210ml, Gomutra-12oml }\end{array}$ & Sthoulya \\
\hline 6 & Panchatiktaksheerabasti & Tiktavargadravya, milk, ghruta & $\begin{array}{l}\text { Asthipradoshaja } \\
\text { Vikara }\end{array}$ \\
\hline 7 & Ksheerbasti & Drug -1 Parts, Ksheera - 8 Parts, Water-32 Parts. & Amlapitta, Parinamshool \\
\hline 8 & PanchaprasrutikaBasti & $\begin{array}{l}\text { Ksheer- 20oml, Madhu- 10oml, Taila-10oml , Ghruta-10oml, } \\
\text { Saindhava }\end{array}$ & $\begin{array}{l}\text { Asthidhatu } \\
\text { pradoshaja Vikaar } \\
\text { (Disease-related bones) }\end{array}$ \\
\hline 9 & Yapanbasti & $\begin{array}{l}\text { Madhu, Sneha, Saindhava Lavana, Kalka- Specific kalkadravya } \\
\text { like Shatpushapa, Madhuyasti, Kutaja, Rasanjana, Saindhava and } \\
\text { Priyangu } \\
\text { Kwatha- Musta, Bala, Rasana, Katurohini, Punarnava, Gudhuchi, } \\
\text { Prushnaparni, Kantakari, Ushira, Aragvadha, Bibhitaka, Trayama- } \\
\text { na, Manjishtha, Shaliparni, Gokshur, Bruhati, MadanphalaKshira }\end{array}$ & SaptaDhatu vrdhaka \\
\hline 10 & Madhutailika Basti & $\begin{array}{l}\text { Erandamula Quath, Shatpushpachurna, Saindhava, Madanphala } \\
\text { and Madhu and taila }\end{array}$ & $\begin{array}{l}\text { Saptadhatu } \\
\text { vardhaka, Klaibya, } \\
\text { Ksheenta, }\end{array}$ \\
\hline 11 & Yuktaratha Basti & $\begin{array}{l}\text { Vacha, Saindhaav, Pimpali, Madanphala, Madhu, Taila, Erandamu- } \\
\text { laquath, Mamsarasa }\end{array}$ & $\begin{array}{l}\text { Katishula, PravaasGrasit, } \\
\text { Parshwashula }\end{array}$ \\
\hline 12 & Siddha Basti & $\begin{array}{l}\text { Yava, Kola, Kulattha, Pippali, Yashtimadhu, Saindhava, Madhu, } \\
\text { Taila }\end{array}$ & Upachyaya, Ksheen \\
\hline 13 & Dhanwanter Basti- & $\begin{array}{l}\text { Dhanvantari tail made up of BalaMoola, Yava, kola, Kulatha, } \\
\text { Dashmula, Jivaniyagana, Daruharidra, Manjishtha, Chandan, } \\
\text { Sariva, Tagara, Triphala,Til oil, Cow milk }\end{array}$ & Vataroga \\
\hline 14 & Manjishtadikwath Basti & $\begin{array}{l}\text { SaindhavaLavana } 5 \mathrm{gm}, \text { Manjishthadi Kalka } 40 \mathrm{gm} \text {, MurchitaTila- } \\
\text { Taila 6o ml, Madhu 8o ml ManjishthadiKwath } 100 \mathrm{ml} \text { [Manjishtha, } \\
\text { Triphala, Guduchi, NimbaTwak, Shatapushpa] } \\
\text { Gomutra } 100 \mathrm{ml} \text {, Kanji } 100 \mathrm{ml} \text { Total } 480 \mathrm{ml}\end{array}$ & $\begin{array}{l}\text { Peripheral arterial } \\
\text { disease }\end{array}$ \\
\hline 15 & Sahacharadi & $\begin{array}{l}\text { Kalka, Sneha and Kwatha should be taken in 1:4:16 ratio. } 1 \text { part } \\
\text { of Kalka of Sahachara (Barleriaprionitis), Nagara (Zingiberoffici- } \\
\text { nalis), Devadaru (Cedrusdeodara), } 4 \text { parts TilaTaila and } 16 \text { part } \\
\text { Kwatha of Sahachara, Devadaru and Nagara }\end{array}$ & Neurological \\
\hline 16 & Madhuyashtyadi & $\begin{array}{l}\text { Madhu, Saindhavalavana, Yashtimadhu tail, Shatpushpakalka and } \\
\text { ErandaMulaQuath }\end{array}$ & Amlapitta \\
\hline 17 & Pipplyadi & $\begin{array}{l}\text { Pipali, Madhuka, Bilva, Shatahva, Madan, Vacha,Kustha, Shati, } \\
\text { Pushakaramula, Chitraka, Deavdaru, Tilataila, Cow milk }\end{array}$ & Parikartika \\
\hline 18 & Kheerbala & Bala 10 gms, Milk $160 \mathrm{ml}$, tila oil $4 \mathrm{oml}$ & Infertility \\
\hline
\end{tabular}


Table 1: (Continued)

\begin{tabular}{|c|c|c|c|}
\hline $\begin{array}{l}\text { Sr. } \\
\text { No. }\end{array}$ & Basti Prakar & Ingredients & Diseases \\
\hline 19 & Murivenna & $\begin{array}{l}\text { Karanja Bark, Kumari Leaves, Tambul, Shigru, Murivenna Taila, } \\
\text { Vatasthbh, Kinshuka Leaves, Vasukam Whole plant, Palandu } \\
\text { Bulb, Shatavari. }\end{array}$ & Asthibhagna \\
\hline 20 & $\begin{array}{l}\text { ChandanaBalaLakshadi } \\
\text { tail Basti }\end{array}$ & $\begin{array}{l}\text { Chandana, Bala, Laksha Sesame oil(Til Oil), Bala (Bheda), Ashwa- } \\
\text { gandha, Bala, Darvi, Murva, Musta, Twaka, Tamalptra, Nagkse- } \\
\text { hara, Raasna, Laksha, Shati, Pittsaar, Sariva, SovarchalLavana, } \\
\text { Rock salt }\end{array}$ & Katigatvat \\
\hline 21 & Erandmooladi & $\begin{array}{l}\text { Kwatha (decoction) Dravya: } 480 \text { ml Erandamula } 10 \text { g, Rasna Root } \\
\text { 10 g, Bala Whole plant } 10 \text { g, Devadaru Heartwood } 10 \text { g, Sahachara } \\
\text { Whole plant } 10 \text { g, Kalka (herbal paste) Dravya: } 40 \text { gm Madana } \\
\text { Phala Fruit 7.o g, Musta Rhizome } 6.6 \text { g, Vacha Bark } 6.6 \text { g, Punar- } \\
\text { nava Whole plant } 6.6 \text { g, Pippali Fruit } 6.6 \text { g, Sarshapa Fruit } 6.6 \text { g, } \\
\text { Murchita Tila Taila Sesame oil - 8o ml Saindava Rock salt - } 5 \text { g } \\
\text { Madhu Honey - } 80 \text { ml Godugdha Milk - } 200 \text { ml }\end{array}$ & Osteoporosis \\
\hline 22 & Madhutailik & $\begin{array}{l}\text { Erandmoola roots, Shatapushpa fruits, Madanphaal seeds, Honey, } \\
\text { Sesame Oil, and Rock Salt. }\end{array}$ & Diabetes \\
\hline 23 & Dwipanchmooladi & Dashmula, Til oil, Madhu & Vataroga \\
\hline 24 & Balaguduchyadi & $\begin{array}{l}\text { Bala, Guduchi, Daruhardra, Paste of } 16 \text { gms each Jatamansi, Chan- } \\
\text { dan, Kundaru, Ashwagandha, Saral, Rasna, Til Oil }\end{array}$ & Bruna \\
\hline 25 & Saindhavadi & $\begin{array}{l}\text { SaindhavaLavana, Sryashi, Rasana, Shatapushpa, Yavani, Sarjika, } \\
\text { Marich, Sunthi, Kushtha, Sovarchlavan, Vida lavan, Vacha, Ajmo- } \\
\text { da, Madhuka, Jeeraka, PushakrMool, Kana (Pippali), ErandaTaila, } \\
\text { Shtapushpa, Kanji, Mastu (TakraPrakar) }\end{array}$ & Amavata \\
\hline
\end{tabular}

\section{Bastikarmukata (Stepwise Mode of Action of Basti)-}

Before starting Basti Chikitsa some Purvakarmas(pre-treatment) are to be carried out to achieve better results.

Amapachana- It clears the obstruction in Srotas caused by Ama. Amapachana is done with the Deepana, Pachana Dravyas such as Trikatu Churna or Panchkola Churna. When Amapachana is achieved, the Srotomukh becomes clear and Srotas become ready to carry vitiated Doshas from Shakha back to Koshtha.

Snehana (oleation of the body)- Sneha enters the body through tiny pores of the skin by its Anupravana Prabhava. After entering the Srotas, it causes Vishyandana and softness in the body and destroys obstruction in srotas. ${ }^{27}$ It also pacifies Vata as Sneha is Vatashamaka.

Swedana-After proper Snehana, Swedana is done to liquefy the Doshas which obstruct the minute channels. ${ }^{28}$

Thus with the help of these three procedures, Amapachana, Snehana and Swedana Dosha move from Shakha towards Koshtha.
Basti- Any substance present in the body which is not conducive to health is considered as mala. ${ }^{29}$ Vagbhata said that if one ignores to evacuate this Mala properly, it may lead to various diseases such as Prameha, Arsha, Grahani, Medoroga etc.In healthy and empty rectum the absorption is more and in diseased condition and the presence of stool delays absorption ${ }^{30}$ Hence proper excretion of Mala is very essential which is done by Basti.

Bastidravya given through rectal route reaches Pakwashaya which is considered as the main site Vata. As Vata is pacified the disease itself get cured because it is a major causative factor in the disease. Other two Doshas do not have existed without Vata.

\section{VataSthana and so it can alleviate the Vataat.}

According to Ayurveda, water given at the root of the plant gives nutrition to the whole plant similarly the Basti functions. ${ }^{31}$ Guda (rectum) is considered as the Moola of Sharira. It has rich blood and lymph supply. The Bastidravya cross the rectal mucosa and absorption of unionized and lipid-soluble substances from the rectum takes place through the rectal venous plexus. The absorption of the drug from the rectum is according to the laws of transfer of molecules across the biological membrane. It is known as diffusion. Diffusion is 
the transport of molecules from a region of higher concentration to a region of lower concentration. The concentration of Bastidravya is more in the lumen of the rectum and lower in the cells adjacent to the rectum. Thus the molecules of Basti move from the rectum to surrounding cells. Many factors such as physical status of Bastidravya, ingredients of Basti and their solubility, temperature, size of molecules, $\mathrm{pH}$ of gastrointestinal fluid, ionization, the surface area of absorption, vascularity influence the rate of diffusion and absorption.

The constituents of Basti reach up to the small intestine and get absorbed through the gut wall, dispersed in the body and thus exert systemic effects. ${ }^{32}$ The intestine is enclosed by 4 layers viz. Muscular, Submucosal, Serosa land mucosal layer. When Basti is administered, initially Bastidravya comes in contact with the mucosal layer which is most superficial. The layers of the intestine and the villi get the nutrition thereby improving the absorption of micronutrients. These micronutrients enter the circulation and finally reach up to the target organ. These all things would be possible only when the intestine gets purified regularly. The mucous membrane of the intestine can easily absorb the lipid-soluble content and finally thrusts into circulation. Thus drug may deliver to the target tissues and Basti proves effective in curing many diseases.

Furthermore, in Niruhabasti the contents of Basti are Makshika, Saindhava, Sneha, Kalka. Saindhava by its Sukshma. Teekshna and Vyavayiguna spread in the minute channel of the body. ${ }^{33}$ The other Dravyas used to prepare Basti different properties, some are water-soluble and some are fat-soluble and get absorbed accordingly. Sushrut explained how the Basti eliminate the Doshas from the body, Virya of Bastidravya extracts the morbid Doshas from all parts of the body to the Pakwashaya just like the sun which resides in the sky and evaporates the water from the earth surface. Similarly, by its Ushna, Tikshnaguna, Basti not only eliminate the Mala and Apana Vayu but also vitiated Doshas present inside the body along with Bastidravya. ${ }^{34}$

\section{DISCUSSION}

Vāta is considered to be the cause of all type of movements of the body and plays a major role in the pathogenesis of many diseases. It aggravates due to Dhātuksaya (diminution of Dhatu) or by Margavarana(occlusion of its channel by other tissues) ${ }^{35}$ Most of the neurodegenerative disorders occurring in present scenario show Vata dominant symptoms where Vata primarily gets aggravated due to Margavara$n a$ (occlusion), which in turn leads to Dhätuksaya (diminution of Dhatu) leading to the increased provocation of Vāta. Due to this critical mechanism, neurodegenerative diseases become almost incurable, if they are treated late.
Basti administered in the Pakvashaya affects the whole body by its Virya. According to modern science, its action of active principles of drug act on receptors in the gastrointestinal tract which is similar to the enteric nervous system. ENS (Enteric Nervous System) is a considerable group of neurons, it is accomplished with Autonomous reflex without the influence of the central nervous system. More than 500 million neurons are present in the ENS (Enteric Nervous System). Hence it's also called "the second brain". ${ }^{36}$ There are several similarities between CNS -ENS concerning cellular structure, neuropeptide secretion and specific functions and recent studies have shown that there is a great impact of CNS and ENS on each other. ${ }^{37}$ Basti may act on the receptors of the ENS to stimulate the CNS causing secretion of obligatory hormones or other chemicals. It is recognized that the enteric nervous system has a unique capability to arbitrate reflex activity independently of input from the brain or spinal cord. ${ }^{38}$ This suggests that the ENS comprises sensory receptors, primary afferent neurons, interneurons and neurons of the motor. The events regulated, at least in part, by the ENS are numerous, involving motor activity, secretion, absorption, blood flow and interaction with other organs, such as the gall bladder or pancreas. ${ }^{39}$ ENS produces several hormones and around 40 neurotransmitters of the same classes as found in the brain. Moreover, neurons in the gut are supposed to generate as much dopamine as those in the head. Serotonin produced in the gut comes into the blood, it is involved in mending damaged cells in the liver and lungs there. ${ }^{40}$

Basti administered through Guda (rectal route) normalizes Apana Vayu leading to Vatanulomana and improves physiological functioning of Vata. Moreover, Bastidravya spreads all over the body, pacifies the aggravated Dosha along with Vyana Vayu leads to Samyaka Rasa Raktadi Dhatu Nirmana. Samyak Rasa Dhatu leads to the formation of Samyak Rakta, Mamsa and Uttarottar Dhatu. It strengthens the muscle power of the body and promotes tissue regeneration. It improves the function of the bladder, uterus, fallopian tube, and ovary.

Basti is effective on Asthivaha and Majjavaha Srotas also. Purishadhara Kala, the colon membrane, is considered as Asthidhara Kala, the membrane of the bone tissue. ${ }^{41}$ Asthi is important sites of Vata Dosha. Hence, medications are given rectally affect all the tissues up to bone tissue. A significant increase in serum calcium was seen after the course of Basti. Though serum calcium decreased after 90 days, it was still higher than the baseline level. Basti Chikitsa exerts a modifying influence on immune responses by regulating proinflammatory cytokines, immunoglobulins and functional properties of T-cells. ${ }^{42}$

In Rickets, there is decreased absorption of calcium and phosphorus from the intestine, leading to bending and softening of the long bones. The large intestine contains a large 
number of $\mathrm{Ca}-\mathrm{Na}$ ion channels, which take up calcium from the extracellular fluid. ${ }^{43}$

Basti in pregnancy- Nowadays the ratio of normal labour is decreasing rapidly because of lifestyle changes. Administration of Matrabasti during the ending of $8^{\text {th }}$ month and in $9^{\text {th }}$ month of pregnancy helps in the induction of normal labour.

In children- Basti is like nectar in child patient. It is very effective in the development of the baby as it develops paraneuron which stimulates the nervous system. Significant improvement occurs in the case of cerebral palsy.

Agnimandya, Dhatudurbalata and Strotovaigunya are the main pathological conditions for manifestations of any disease. Thus, Basti acts on these factors and improves health. Different types of Basti like Snehabasti, Chakshushyabasti, Madhutailikbasti, Yuktharathbasti, Siddhabasti, Bruhanbasti, Utkleshanbasti, Doshaharbasti, Yapanabasti, Vrishyabasti, Rasayanabasti, can be considered as health promotive. Most of the Dravyas used in these types of Basti like Tail, Ksheer, Madhu, Saindhav, Triphala, Mamsa Rasa etc are significant sources of protein, vitamins and minerals. Different clinical studies have shown that there is a considerable increase in serum proteins, essential fatty acids, vitamin- $\mathrm{k}$, and vitamin Bcomplex levels after the course of Basti treatment.

When the channels of the body are cleaned by Niruha Basti it provides complexion and strength. Anuvasana Basti destroys roughness, lightness and coldness of Vata. Basti provides clarity of mind, energy, and strength to the body. ${ }^{44}$

All the Dhatus gets nourished by Basti enhancing the body's Dhatwagni to maintain Dhatusamya (homeostasis) and increase the immunity of the body towards the invasion of the disease.

\section{CONCLUSION}

Basti is one of the most important and useful treatments for a diseased and healthy person. There are so many types of Basti according to diseases, Rutu, Bala, Kala. So we can consider these factors while adopting the Basti in any person. Basti is not only curative but also disease preventive and health promotive. Basti helps to maintain the equilibrium of Vata dosha in our body. It increases Shukra(potency), Oja (vital energy) and Agni (digestive fire). In this modern era, as per our daily routine, health management is very difficult. So, by the use of Basti Karma, we can manage our hectic lifestyle and make it a healthy life.

\section{REFERENCES}

1. Gaidhane, A., A. Sinha, M. Khatib, P. Simkhada, P. Behere, D. Saxena, B. Unnikrishnan, M. Khatib, M. Ahmed, and Q.S. Zahiruddin. "A Systematic Review on Effect of Electronic Media on Diet, Exercise, and Sexual Activity among Adolescents." In- dian Journal of Community Medicine. 2018; 43( 5 ): S56-65. https://doi.org/10.4103/ijcm.IJCM_143_18.

2. Regmi, P.R., E. van Teijlingen, P. Mahato, N. Aryal, N. Jadhav, P. Simkhada, Q.S. Zahiruddin, and A. Gaidhane. "The Health of Nepali Migrants in India: A Qualitative Study of Lifestyles and Risks." International Journal of Environmental Research and Public Health, 2019, 16(19):23-27. https://doi.org/10.3390/ ijerph16193655.

3. Papalkar, P., S. Kumar, S. Agrawal, N. Raisinghani, G. Marfani, and A. Mishra. "Heterotaxy Syndrome Presenting as Severe Pulmonary Artery Hypertension in a Young Old Female: Case Report." Journal of Gerontology and Geriatrics 2018;66(2): 59-61.

4. Bhinder, H.H.P.S., and T.K. Kamble. "The Study of Carotid Intima-Media Thickness in Prediabetes and Its Correlation with Cardiovascular Risk Factors." Journal of Datta Meghe Institute of Medical Sciences University, 2018; 13(2):79-82. https://doi. org/10.4103/jdmimsu.jdmimsu_58_18.

5. Kamble A, Ambad R, Padamwar M, Kakade A, Yeola M. To study the effect of oral vitamin D supplements on wound healing in a patient with diabetic foot ulcer and its effect on lipid metabolism. Int. J. Res. Pharm. Sci., 2020; 11(2): 2701-2706.

6. Ambad R, Gaikwad S B, Anshula G, Bankar N. Polyherbal antidiabetic drug: An approach to cure diabetes. Int. J. Res. Pharm. Sci., 2020; 11(2):2679-2683.

7. Ambad R, Jha R, Butola L.K., Bankar N, Singh BR, Dhok A. Relationship between uric acid and creatinine in pre-diabetic and diabetic patients: Vidarbha region of Maharashtra. Int. J. Res. Pharm. Sci., 2020; 11(3): 3412-3417.

8. Arya, S., H. Deshpande, S. Belwal, P. Sharma, P. Sadana, Chandrakant, F. Rahman, M. Gupta, and B. Uniyal. "Association between Cardiac Dysfunction, Arrhythmias and Chronic Liver Diseases: A Narrative Review." Trends in Anaesthesia and Critical Care, 2020. https://doi.org/10.1016/j.tacc.2020.03.003.

9. Charak S, Vidyotini Hindi commentary by Pandey K Chaturvedi G, Bharati C Academy, Varanasi, Edition 1998;2: 40-41.

10. Yadaiah P. 2nd ed. Jay Mudran Company; Akola: 2008. Clinical Panchakarma (English); 93-94.

11. Vagbhata, Hrudaya A, Vidyotini commentary by Gupta KA, Sansthan CS, Varanasi, ed 2000; 12(1): 90 .

12. Aracharya $\mathrm{S}$, arasamhita $\mathrm{A}$, translated by Dr. Himasagara $\mathrm{P}$. Murthy C, Chowkhamba Sanskrit Series Office, Varanasi Ed. $2013 ; 5(25) ; 44$.

13. Samhita S, Vol. 1 Ayurved Tattva Sandipika commentary by Shastri KA, Sanskrit C, Varanasi C, ed. 2007; 1(19):230.

14. Samhita C.C, Vol.2, Vidyotini Hindi commentary by Pandey K and Chaturvedi G, Chaukhambha Bharati Academy,Varanasi, Edition 1998; 1(27); 968

15. Sushrut, Samhita S, Vol. 1 Ayurved Tattva Sandipika commentary by Kaviraj Ambikadatta Shastri,Chaukhamba Sanskrit SansthanVaranasi, ed. 2007;35(24):155.

16. Charak, Samhita C, Vidyotini Hindi commentary by Kashinath Pandey and Gorakhnath Chaturvedi, Chaukhambha Bharati Academy, Varanasi, Edition 1998; 1(39): 971.

17. Sushrut, Samhita S, Vol. 1 Ayurved Tattva Sandipika commentary by Kaviraj Ambikadatta Shastri, Chaukhamba Sanskrit SansthanVaranasi, ed. 2007; Chikitsasthana 35(18): 154.

18. Charak, Samhita C, Vol. 2, Vidyotini Hindi commentary by Kashinath Pandey and Gorakhnath Chaturvedi, Chaukhambha Bharati Academy, Varanasi, Edition 1998, Siddhisthana 3(30): 996.

19. Sushrut, Samhita S, Vol. 1 Ayurved Tattva Sandipika commentary by Kaviraj Ambikadatta Shastri,Chaukhamba Sanskrit SansthanVaranasi, ed. 2007; Chikitsasthana 35(18): 154 .

20. Charak, Samhita C, Vol.2, Vidyotini Hindi commentary by Kashinath Pandey and Gorakhnath Chaturvedi, Chaukhambha 
Bharati Academy, Varanasi, Edition 1998, Siddhisthana 1(47): 973.

21. Sushrut, Samhita S, Ayurved Tattva Sandipika commentary by Kaviraj Ambikadatta Shastri, Chaukhamba Sanskrit SansthanVaranasi, ed. 2007; Sutrashtana 21(20):91.

22. Charak, Samhita C, Vol.2, Vidyotini Hindi commentary by Kashinath Pandey and Gorakhnath Chaturvedi, Chaukhambha Bharati Academy, Varanasi, Edition 1998, Siddhisthana1(27-34): 682 .

23. Charak, Samhita C, Vol.1, Vidyotini Hindi commentary by Kashinath Pandey and Gorakhnath Chaturvedi ,Chaukhambha Bharati Academy,Varanasi,Edition 2003, Sutrasthana 28/27 ;573p.

24. Aracharya S, Sarangdharasamhita, translated by Dr. P. Himasagara Chandra Murthy, Chowkhamba Sanskrit Series Office,Varanasi Ed. 2013, Madhyama Kanda Chapter 2/161;139p.

25. Charak, Samhita C, Vol.2, Vidyotini Hindi commentary by Kashinath Pandey and Gorakhnath Chaturvedi ,Chaukhambha Bharati Academy,Varanasi,Edition 1998,. Siddhisthana 12/17-1 2002; p.981

26. Das G, Ratnavali B, edited by Bramhashankar Mishra, Vidyotini Hindi commentary by Kaviraj Ambikadatta Shastri, Chaukhamba Prakashana, $18^{\text {th }}$ ed.2019,29/222-227

27. Charak, Samhita C, Vol.1, Vidyotini Hindi commentary by Kashinath Pandey and Gorakhnath Chaturvedi ,Chaukhambha Bharati Academy,Varanasi,Edition 2003, Sutrasthana 22/11; $424 \mathrm{p}$.

28. Charak, Samhita C, Vol.2, Vidyotini Hindi commentary by Kashinath Pandey and Gorakhnath Chaturvedi ,Chaukhambha Bharati Academy,Varanasi,Edition 1998,. Siddhisthana 1(7): 960.

29. Vagbhata, Hrudaya A, Vidyotini commentary by Kaviraj Atridev Gupta, Chaukamba Sanskrit Sansthan, Varanasi, ed 2000; Sutrasthana1/13:7.

30. Satoskar, Bhandarkar. ParmacologyandPharmacotherapeutics, 2013;12(1): 4.

31. Charak, Samhita C, Vol.2, Vidyotini Hindi commentary by Kashinath Pandey and Gorakhnath Chaturvedi, Chaukhambha Bharati Academy,Varanasi,Edition 1998,. Siddhisthana 1:31;
32. Charak, Samhita C, Vol.2, Vidyotini Hindi commentary by Kashinath Pandey and Gorakhnath Chaturvedi ,Chaukhambha Bharati Academy,Varanasi,Edition 1998,. Siddhisthana 1:40

33. Bhavamishra, Nighantu B, Vidyotini commentary by Shri. Bramhashankar Mishra and RupalaljiVaishya, Chaukhamba Sanskrit Bhavan Ed.12 2016 Part 1 Haritakyadi varga /241- 345.

34. Sushrut, Samhita S, Vol. 1 Ayurved Tattva Sandipika commentary by Kaviraj Ambikadatta Shastri,Chaukhamba Sanskrit SansthanVaranasi, ed. 2007; Chikitsasthana 25/26,27,28

35. Vagbhata, Hrudaya A, Vidyotini commentary by Kaviraj Atridev Gupta, Chaukamba Sanskrit Sansthan, Varanasi, ed 2000;Nidansthana 15/5-6: 276

36. The Second Brain | Our Enteric Nervous System, available from http://www.mfi-therapy.com/thesecond-brain-our-enteric-nervous-system/(cited on 11 sep 2015)

37. Enteric nervous system, available from http://www.scholarpedia.org/article/ Enteric_nervous_system\#ENS-CNS_interactions (cited on 11 sep 2015)

38. Wood JD. Physiology of the enteric nervous system. In: Johnson LR, ed. Physiology of the gastrointestinal tract, 3rd edn. New York: Raven Press, 1994:423-82.

39. Goyal RK, Hirano I.The enteric nervous system. N Engl J Med 1996; 334:1107-15.

40. The Second Brain | Our Enteric Nervous System, available from http://www.mfi-therapy.com/thesecond-brain-our-enteric-nervous-system/(cited on 11 sep 2015)

41. Sushrut, Sushrut Samhita, Nibandhasangraha by Sri Dalhanacharya, translated by Achaarya Y.T. Chaukhamba Orientalia, Varanasi, $4^{\text {th }}$ ed. 1980; Kalpasthana 4:40.

42. Thatte U, Chiplunkar S, Bhalerao S, Kulkarni A, Ghungralkar $\mathrm{R}$, Panchal $\mathrm{F}$, et al.Immunological and metabolic responses to a therapeutic course of basti in obesity. Indian J Med Res., 2015 Jul. 142(1): 53-62.

43. Dietary Reference Intakes for Calcium and Vitamin D. Institute of Medicine (US) Committee to Review Dietary Reference Intakes for Vitamin D and Calcium; Ross AC, Taylor CL, Yaktine AL, et al., editors.Washington (DC): National Academies Press (US); 2011

44. Charak, Charak Samhita, Vol.2, Vidyotini Hindi commentary by Kashinath Pandey and Gorakhnath Chaturvedi ,Chaukhambha Bharati Academy, Varanasi, Edition 1998, Siddhisthana.1:29-30. 